\title{
IMAGINAÇÃO, TRANSGRESSÃO E FORMALIZAÇÃO: AÇÕES DO CONGRESSO E DO STF NA DEFINIÇÃO DE REGRAŞ DE TRAMITAÇÃO DE MEDIDAS PROVISÓRIAS
}

\section{IMAGINATION, TRANSGRESSION AND FORMALIZATION: ACTS BY THE BRAZILIAN CONGRESS AND SUPREME FEDERAL COURT CONCERNING PROVISIONAL MEASURES' PROCEDURAL RULES}

\author{
LEANDRO MOLHANO RIBEIRO ${ }^{1}$
}

MARIANA NOVOTNY MUNIZ ${ }^{2}$

RESUMO: As regras constitucionais referentes à tramitação de medidas provisórias sofreram diversas mudanças desde a promulgação da Constituição de 1988. Algumas dessas mudanças foram formais, como é o caso da Emenda Constitucional 21 e outras informais. $\mathrm{O}$ artigo analisa quatro casos em que as regras foram alteradas informalmente, por meio de imaginação política ou transgressão. Ainda, busca-se dividir os casos de mudança institucional em quatro diferentes tipos, sendo eles: displacement, layering, drift ou conversion. Por fim, argumenta-se que o Supremo Tribunal Federal tem a palavra final sobre as disputas interpretativas, formalizando-as, em caso de imaginação, ou vetando-as em caso de transgressão.

PalavRAs-Chave: Mudança institucional; Medidas Provisórias; Supremo Tribunal Federal; Processo legislativo.

\footnotetext{
${ }^{1}$ Professor Escola de Direito do Rio da Fundação Getulio Vargas. Contato: leandro.ribeiro@fgv.br.

2 Graduanda em Direito na Fundação Getulio Vargas (FGV Direito Rio). Contato: marinmuniz5@gmail.com.
} 
ABSTRACT: The constitutional rules concerning provisional measures have been frequently altered since the Brazilian Constitution was promulgated in 1988. Some of these changes were formally made, such as the 21st Constitutional Amendment, while others were informally processed. The article seeks to analyze four cases in which the rules were informally altered, either through political imagination or transgression. These cases were also classified into four different types of institutional change: displacement, layering, drift or conversion. Finally, the authors contend that the Brazilian Supreme Federal Court has had the final word regarding these changes, formalizing them when the rules were reinterpreted or vetoing them when the rules were infringed.

KeYWORDS: Institutional change; Provisional Measures; Brazilian Supreme Court; Legislative process.

\section{INTRODUÇÃo}

O presidencialismo de coalizão que caracteriza o sistema político brasileiro é o resultado de um duplo processo institucional de concentração de poderes inscrito da Constituição Federal de $1988^{3}$. Por um lado, o Poder Executivo foi contemplado pelos constituintes com amplos poderes legislativos, como a exclusividade de propor projetos de lei sobre determinadas matérias, alterar o timing do fluxo do processo de decisório por meio de pedidos de urgência para projetos de lei em votação e pela possibilidade de legislar por medida provisória (MP) - instrumento normativo que permite ao Presidente da República adotar medias com força de lei em casos de relevância e urgência. Por outro, as presidências da Câmara e do Senado concentraram o poder de agenda dentro do legislativo. O Colégio de Líderes, formado por líderes da Maioria, Minoria, dos Partidos, Blocos Parlamentares e do Governo, também foi institucionalizado pela Câmara dos Deputados por meio de seu regimento e deve ser consultado nas decisões que organizam os trabalhos na Câmara, como a definição da composição das Comissões Permanentes e Especiais e da agenda de proposições que serão apreciadas na Casa. Ao Senado foi atribuído um poder de legislar equiparável ao da Câmara dos Deputados, configurando um bicameralismo em que aquele não é apenas uma instituição revisora, mas tem a capacidade de iniciar legislação. Câmara e Senado podem alterar projetos iniciados na outra casa, voltando para apreciação da casa

\footnotetext{
${ }^{3}$ A literatura a respeito do presidencialismo de coalizão brasileiro é extensa. Não pretendemos aqui descrever o seu funcionamento de forma detalhada, mas apenas chamar a atenção para a importância da medida provisória como recurso de poder de agenda legislativo conferido ao Executivo pela Constituição Federal de 1988. A síntese do funcionamento do presidencialismo de coalizão apresentada neste artigo se baseia em Figueiredo e Limongi (1999) e Abranches (2018).
} 
original. $\mathrm{O}$ fato de o partido do Presidente dificilmente conseguir maioria em ambas as casas legislativas faz com que o Presidente tenha que negociar suas políticas públicas com uma base parlamentar de apoio - daí a configuração da coalizão que caracterizaria nosso presidencialismo.

Nesse sistema em que poderes de agenda e de veto ${ }^{4}$ são distribuídos entre Executivo, Câmara dos Deputados e Senado, o poder de editar medidas provisórias é um recurso do Executivo que aumenta o seu poder de agenda legislativa em detrimento do Legislativo. Como as medidas provisórias passam a ter eficácia no momento de sua edição, alterando o status quo imediatamente, rejeitá-las tem um alto custo para o Congresso e reverter seus efeitos é, até mesmo, impossível. É praticamente consensual na literatura sobre o tema que esse poder conferido ao Executivo foi ainda ampliado com a possibilidade de reedição de MPs, regra que vigorou até a promulgação da Emenda Constitucional 32 (EC 32) em 2001 que a vedou.

Como recurso que confere intenso poder de agenda ao Executivo, é natural que as regras que regulam o uso de MPs tenha sido objeto de frequentes disputas pelos parlamentares brasileiros. A EC 32, que alterou significativamente a redação do artigo 62 da Constituição Federal, teve entre uma das suas principais alegadas motivações limitar o uso abusivo do poder de legislar pelo Executivo por meio de reedições de MPs (MACHIAVELI, 2009; ABREU JUNIOR, 2002).

Embora as regras referentes à edição de MPs possam parecer precisas, elas tiveram seu conteúdo frequentemente alterado ou negligenciado pelos parlamentares. Exemplos disso são 1) a possibilidade de reedição de MPs; 2) a definição de que atividades legislativas devem ser consideradas "deliberações legislativas" e, consequentemente, o alcance do sobrestamento da pauta (artigo 62, parágrafo $\left.6^{\circ}, \mathrm{CF} / 88\right)$; 3) divergências sobre a necessidade das MPs passarem obrigatoriamente por Comissão Mista antes da votação (artigo 62, parágrafo 9ㅜㅡㄴ $\mathrm{CF} / 88$ ), tendo consequências para a definição do momento preciso em que se inicia a contagem do prazo para o sobrestamento da pauta; 4) a definição do conteúdo de emenda à MP que deve ser considerado "estranho" à matéria e, por isso, não pode ser incluído pelos parlamentares na tramitação da MP.

Além da mudança constitucional promovida pela EC 32, a regulamentação do uso de medidas provisórias passou por definições e alterações importantes ao longo de toda sua história desde 1988. Essas interpretações são importantes porque, como qualquer instituto que organiza o fluxo do processo decisório, as regras de tramitação das MPs distribuem recursos entre os atores políticos relevantes ao definir poderes de agenda e de veto desses atores. As disputas interpretativas a

${ }^{4} \mathrm{O}$ processo decisório é caracterizado, entre outras coisas, por uma sequência de interação em que alguns atores têm o poder de apresentar uma proposta inicial e outros com o poder de rejeitá-la. Aqueles que iniciam a "jogada", denominados "agenda settters", tem a vantagem de propor algo que seja o mais próximo possível à sua preferência e, ao mesmo tempo, aceitável para aqueles que com o poder de vetá-la. Tsebelis (2002). 
respeito da tramitação de MPs são evidenciadas nos diversos debates e projetos protocolados no Congresso Nacional propondo o seu redesenho, nas diversas Questões de Ordem $(\mathrm{QO})$ levantadas no Congresso a seu respeito e em várias ações no STF contestando ou afirmando as interpretações dadas pelos parlamentares a seu respeito. Argumentamos neste artigo que, nestas ocasiões, ocorreram alterações no trâmite das MPs por meio do que a literatura chama de "transgressão" ou "imaginação" (SHEPSLE, 2017). São definições a respeito do funcionamento das instituições feitas por meio de interpretação por parte de atores políticos que atuam sob elas, tendo consequências importantes para a distribuição de poder de agenda e veto no fluxo do processo decisório. Nessas disputas interpretativas, é possível haver "estratagemas" que, embora mantenham as regras formalmente inalteradas, redefinem a forma como devem ser aplicadas na prática das atividades políticas.

Um aspecto importante na história da definição das regras de tramitação de MPs é o papel exercido pelo STF na formalização de interpretações que a (re)configuram. É possível identificar um modelo de mudança institucional por transgressão ou imaginação na tramitação de MPs que é "formalizado" por meio da judicialização. Nesse sentido, o STF foi um ator ativo e importante na re(elaboração) das possiblidades e limites do poder de agenda que a MP proporciona ao Executivo. Por sua vez, a entrada do STF como uma espécie de árbitro interpretativo nesses casos abre a possibilidade para que ele amplie seu próprio poder, ao tomar decisões a respeito da tramitação legislativa interna ao Congresso ${ }^{5}$. Este artigo explora a relação entre o Congresso, especialmente a Câmara dos Deputados, e o STF nas interpretações a respeito do desenho institucional da MP desde 1988, chamando a atenção para as ações de transgressão e imaginação dos parlamentares que foram refutadas ou formalizadas pelo tribunal.

\section{IMAGINAÇÃO, TRANSGRESSÃO E MUDANÇA INSTITUCIONAL}

Como amplamente reconhecido pela literatura, instituições, entendidas como regras formais e informais ${ }^{6}$, delimitam os atores que podem atuar no processo decisório, o escopo de suas ações e o momento em que podem agir (MAHONEY; THELEN, 2010; SHEINGATE, 2010; SHEPSLE, 2017). Instituições, portanto, distribuem poderes aos atores políticos e definem, consequentemente, os parâmetros a partir dos quais estes calculam sua força política e os custos e benefícios de suas interações estratégicas. Entendidas nesse sentido, as regras que

\footnotetext{
${ }^{5}$ Uma explicação para os atores políticos judicializarem essas questões e, em alguma medida, permitirem a interferência do STF em assuntos internos pode ter a ver com o fato de que, neste modo de mudança institucional, haveria poucos custos de superar o status quo bias das instituições políticas (PIERSON, 2004).

${ }^{6}$ A definição de instituições como regras formais e informais, amplamente aceita na literatura, foi formulada por Douglas North (1990).
} 
orientam o trâmite das MPs definem os atores que podem agir no seu fluxo processual, seu escopo de atuação e a sequência da interação entre eles; distribuem, portanto, os poderes de agenda e de veto aos atores do Executivo e do Legislativo na tramitação de MPs.

Como mencionado anteriormente, a Medida Provisória é um instrumento normativo que confere grande poder legislativo ao Executivo brasileiro. O instituto foi incluído na Constituição de 1988 e tinha a seguinte redação originalmente:

Artigo 62: Em caso de relevância e urgência, o Presidente da República poderá adotar medidas provisórias, com força de lei, devendo submetê-las de imediato ao Congresso Nacional, que, estando em recesso, será convocado extraordinariamente para se reunir no prazo de cinco dias.

Parágrafo único. As medidas provisórias perderão eficácia, desde a edição, se não forem convertidas em lei no prazo de trinta dias, a partir de sua publicação, devendo o Congresso Nacional disciplinar as relações jurídicas delas decorrentes. (BRASIL, 1988)

Observa-se que orginalmente, a MP conferia ao Executivo a possibilidade de alterar imediatamente o status quo com a sua edição e deixava ao Legislativo a escolha entre mantê-lo alterado ou rejeitar a MP, arcando com os custos de disciplinar as relações jurídicas do contexto já modificados por ela. Ao inviabilizar o retorno ao status quo original, as MPs são percebidas como instrumentos poderosos de indução de cooperação entre Executivo e Legislativo (Figueiredo e Limongi, 1999). A importância da MP como recurso político nas mãos do Executivo pode ser observada no fato de que todos os planos econômicos de controle da inflação foram implementados por MPs (ABRANCHES, 2018). Além disso, todos os presidentes desde a redemocratização fizeram amplo uso de MPs para implementar suas políticas públicas. ${ }^{7}$

A EC 32 alterou o artigo 62 com o objetivo declarado de reduzir o elevado poder de agenda do Executivo. ${ }^{8}$ Para isso, promoveu as seguintes alterações: vedou a edição de medidas provisórias em determinadas matérias ${ }^{9}$; proibiu a reedição de

\footnotetext{
7 Segundo Abranches (2018), entre 1988 e 2017 foram editadas 1427 MPs.

${ }^{8}$ De acordo com João Paulo de Oliveira, ex-Procurador da Fazenda Nacional, destaca-se - entre as razões motivadoras para a promulgação da Emenda Constitucional 32, a "inequívoca proliferação de medidas provisórias", tendo a Emenda "como principal objetivo o de restringir a possibilidade de edição de novas medidas provisórias."

${ }^{9}$ De acordo com o $\S 1^{\circ}$ estão vedadas MPs a respeito de "a)nacionalidade, cidadania, direitos políticos, partidos políticos e direito eleitoral; b) direito penal, processual penal e processual civil; c) organização do Poder Judiciário e do Ministério Público, a carreira e a garantia de seus membros; d) planos plurianuais, diretrizes orçamentárias, orçamento e créditos adicionais e suplementares, ressalvado o previsto no art. 167, § 3; II - que vise a detenção ou sequestro de bens, de poupança popular ou qualquer outro ativo financeiro; III - reservada a lei complementar;
} 
$\mathrm{MPs}^{10}$; alterou o prazo de vigência das MPs de 30 dias prorrogáveis indefinidamente por 60 dias prorrogáveis apenas uma vez pelo mesmo período de tempo ${ }^{11}$; incluiu o sobrestamento de pauta a partir do $45^{\circ}$ dia de vigência da MP não apreciada pelo Congresso ${ }^{12}$; vinculou a deliberação da Câmara e do Senado sobre o mérito das MPs a uma avalição prévia da sua constitucionalidade ${ }^{13} \mathrm{e}$ determinou que uma Comissão Mista deveria examinar as MPs antes da sua apreciação na Câmara e no Senado ${ }^{14}$. A EC 32 manteve a alteração imediata do status quo através da edição de MP pelo Executivo, mas tornou o rito de tramitação das MPs mais complexo ao promover uma maior interação entre Executivo e Legislativo para sua apreciação (MACHIAVELI, 2009) ${ }^{15}$. Com a proibição da reedição de MPs pela EC 32, esperava-se, também, uma diminuição no uso desse instrumento pelo Executivo. Mas não foi isso o que aconteceu. Levando em conta o número de MPs originais editadas (sem reedição, portanto), o número passou de uma média de 40 MPs entre 1995 e 2001 para uma média de 60 entre 2002 e 2007 (Pires, 2008). Além disso, com a inclusão do sobrestamento da pauta, o Congresso passou a ter um prazo relativamente curto para apreciar MPs, sob o risco de ter suas atividades legislativas paralisadas. $\mathrm{E}$ foi isso que ocorreu. O percentual de pautas livres na Câmara dos Deputados passou de 2,2\% em 2001 para 36\% já em 2002, permanecendo neste patamar em 2006 e 2007 (Pires, 2008). Isso significa que, mesmo com a EC 32, as MPs ainda conferem um elevado poder legislativo ao Executivo.

Dada a importância das MPs para o processo político decisório brasileiro, as regras do artigo 62 da CF que disciplinam sua tramitação sempre estiveram sujeitas à interpretação dos parlamentares. Como lembra Adam Sheingate (2010), as

IV - já disciplinada em projeto de lei aprovado pelo Congresso Nacional e pendente de sanção ou veto do Presidente da República."

10 "§ 10. É vedada a reedição, na mesma sessão legislativa, de medida provisória que tenha sido rejeitada ou que tenha perdido sua eficácia por decurso de prazo."

11 "§ $7^{\circ}$ Prorrogar-se-á uma única vez por igual período a vigência de medida provisória que, no prazo de sessenta dias, contado de sua publicação, não tiver a sua votação encerrada nas duas Casas do Congresso Nacional."

12 "§ 6 $6^{\circ}$ Se a medida provisória não for apreciada em até quarenta e cinco dias contados de sua publicação, entrará em regime de urgência, subsequentemente, em cada uma das Casas do Congresso Nacional, ficando sobrestadas, até que se ultime a votação, todas as demais deliberações legislativas da Casa em que estiver tramitando."

13 "§ $5^{\circ}$ A deliberação de cada uma das Casas do Congresso Nacional sobre o mérito das medidas provisórias dependerá de juízo prévio sobre o atendimento de seus pressupostos constitucionais."

14 "9o Caberá à comissão mista de Deputados e Senadores examinar as medidas provisórias e sobre elas emitir parecer, antes de serem apreciadas, em sessão separada, pelo plenário de cada uma das Casas do Congresso Nacional."

${ }^{15}$ Segundo Machiaveli, apesar de ter o objetivo declarado de limitar o abuso do poder de legislar do Executivo por meio de reedições de MPs, o texto aprovado foi mais favorável ao Executivo do que as propostas que estavam em discussão no Congresso. 
próprias regras que organizam o processo decisório empoderam os atores relevantes, ao permitir que eles definam seu conteúdo "regulativo", normativo e cognitivo. Isso ocorre porque a linguagem carece de total determinação, contendo expressões ou termos ambíguos ou vagos. Tais termos abrem a possibilidade para disputas interpretativas em torno da incidência e aplicação da regra, algo que ocorreu diversas vezes com as regras relativas ao trâmite de MPs.

O tipo de mudança institucional acarretado por disputas interpretativas é conhecido na literatura especializada como mudança gradual (MAHONEY; THELEN, 2010). De acordo com Mahoney e Thelen (2010), diferentemente de alterações institucionais promovidas por fatores exógenos - como mudanças abruptas e/ou de larga escala na economia, no contexto social vigente, etc. - é possível haver mudanças graduais promovidas por atores que atuam dentro das instituições (mudanças por fatores endógenos) - normalmente alterações incrementais.

As mudanças institucionais previstas por Mahoney e Thelen podem ser de quatro tipos: displacement (substituição das regras vigentes por novas), layering (adoção de novas regras ao lado das existentes); drift (formalmente a regra permanece, mas há uma mudança no seu impacto, por exemplo, pelo fato dos atores a negligenciarem); e conversion (formalmente as regras permanecem, mas há mudança na sua interpretação e aplicação). A mudança institucional pode estar relacionada a dois fatores: 1) um contexto político em que a possibilidade veto à mudança é forte ou fraca (atores de veto fortes) e 2) se as regras estão sujeitas a uma maior ou menor discricionariedade em relação a sua interpretação e enforcement. Assim, displacement e layering normalmente ocorrem quando há baixa possibilidade de interpretação a respeito das regras vigentes. Já drift e conversion ocorrem sem situações em que há elevado nível de discricionariedade em relação ao significado das regras devido à sua ambiguidade ou vagueza. ${ }^{16}$

A forma como essas diferentes possibilidades de mudanças endógenas é produzida pelos atores políticos pode ser dar por meios formais, previstos nas próprias regras existentes, ou por imaginação ou transgressão (violação) por parte dos atores políticos (SHEPSLE, 2017). Formalmente, diversos mecanismos de revisão incorporados nas próprias regras possibilitam mudanças institucionais, como procedimentos de emendas, possibilidades de interpretação judicial, "cláusulas de escape", anulações, poderes emergenciais. Estes mecanismos seriam previstos justamente para permitir uma adaptação a mudanças circunstanciais não previstas inicialmente por aqueles que criaram as regras. A imaginação e a transgressão, por sua vez, são maneiras informais de alterar as instituições. A imaginação pode ser definida como um exercício de reinterpretação de uma margem controversa da regra, havendo a criação de um novo "caminho" não

${ }^{16} \mathrm{O}$ modelo analítico de Mohoney e Thelen contempla uma outra tipologia: a dos atores que primordialemente promovem os tipos de mudança descritos. Nesse caso, drift e conversion seriam produzidos respectivamente por atores tipicamente "parasitic symbionts" e "oportunistas". 
antecipado e/ou não percebido antes pelos atores relevantes. A imaginação envolve algum tipo de estratagema ou "esperteza" por parte dos atores que a emprega. A transgressão ocorre quando há simplesmente a quebra da regra. Uma combinação entre resultados de mudança e forma parece sugerir que a transgressão e imaginação, a princípio, se associariam mais à mudança de tipo drift e conversion, na medida em que são situações mais suscetíveis à interpretação.

Na seção seguinte mostraremos que esses tipos de mudança incremental foram implementados por meio de uma combinação com estratégias de transgressão ou imaginação por parte dos parlamentares a respeito da aplicação das regras de tramitação das MPs. As interpretações a respeito desses temas são importantes porque definem o grau de poder de agenda do Executivo na edição de MPs e o alcance do poder de veto de parlamentares na sua tramitação. Em todas essas situações, os conflitos interpretativos "resolvidos" pelos parlamentares a respeito das regras de tramitação foram judicializados e, com isso, a palavra final sobre elas foi dada pelo STF. Em grande medida, portanto, as mudanças informais no instituto da MP produzidas pelo Executivo e pelo Legislativo seguiram uma dinâmica em que uma solução dada pelo próprio Congresso era confirmada ou negada pelo STF, conferindo a este poder uma atuação relevante na definição do desenho do processo decisório da MP.

\section{MUdANÇAS INSTITUCIONAIS DAS MPS: INTERAÇÕES INTERPRETATIVAS ENTRE O CONGRESSO E STF}

\section{Reedição de Medidas Provisórias}

Provavelmente a primeira interpretação importante a respeito da tramitação de medidas provisórias tenha sido a decisão a respeito da possibilidade de sua reedição. Como se sabe, a reedição de MPs foi amplamente usada pelos governos brasileiros entre 1989 e 2001 (ABRANCHES, 2018). O uso considerado abusivo de reedição de MPs foi uma das principais justificativas para a elaboração da Emenda Constitucional 32 (MACHIAVELI, 2009). O diagnóstico compartilhado na literatura especializada e nas declarações de atores políticos era o de que a possibilidade de reeditar medidas provisórias dotou o poder Executivo de excessivo poder de agenda em detrimento do Legislativo. A reedição era vista, portanto, como um recurso legislativo do Executivo que desequilibrava a separação de poderes no país e, consequentemente, esvaziava a capacidade de legislar do Congresso Nacional.

A reedição de MPs não estava prevista originalmente na Constituição de 1988. Ela foi implementada pelo Executivo e posteriormente discutida no Congresso. Em 1989, uma interpretação dada pelo próprio Legislativo, mas não formalizada permitiu a reedição de MPs. Em 1990, o STF se pronunciou a respeito da questão na ADI 295 e, com isso, formalizou a possibilidade de reedição de MPs. No dia 21 
de fevereiro de 1989, o então Presidente da República José Sarney editou a MP 39 que era uma reedição da MP 29 cujo conteúdo dispunha sobre a organização da Presidência da República e dos Ministérios e havia perdido eficácia. $\mathrm{O}$ fato é que o dia anterior (20 de fevereiro), o então senador Fernando Henrique Cardoso havia apresentado um projeto de resolução visando definir normas para o exame e votação de MPs. Pelo projeto de Cardoso, a não votação de MPs pelo Congresso deveria ser considerada como uma rejeição tácita do Legislativo, propondo, ainda a impossibilidade de reedição de MPs. Na ocasião, a mesa da Câmara e a mesa do Senado apresentaram dois substitutivos ao projeto.

O então presidente do Congresso Nacional, Senador Nelson Carneiro, nomeou uma Comissão Mista para analisar a constitucionalidade a respeito da reedição de medidas provisórias e resolver a questão. A relatoria da Comissão ficou a cargo do então Deputado Nelson Jobim, que acabou rejeitando as propostas elaboradas por Cardoso, e defendeu a possibilidade de reedição de MPs que tivessem perdido eficácia. Pelo parecer elaborado pela Comissão Mista, "Na ausência da lei complementar (art. 59 da CF) e diante da necessidade de tomada inadiável de uma decisão, entendemos, transitoriamente, até o advento da mencionada lei, pela admissão da reedição da medida, mesmo porque somente a Lei Complementar pode disciplinar o exercício de um direito subjetivo constitucional."17 O parecer elaborado por Jobim resultou na Resolução 1 do Congresso Nacional, que foi promulgada em maio de 1989. Entretanto, a Resolução não fez menção explícita a respeito da possibilidade reedição de MPs em casos de perda de eficácia, algo que constava do parecer de Jobim. Observa-se, nesse caso, que o Congresso não formalizou a reedição de MPs. O conflito interpretativo a respeito do significado de sua não apreciação, isto é, se a não apreciação poderia ser considerada uma rejeição tácita do Legislativo ou não, só foi resolvida pelo STF um ano depois.

A decisão do STF de permitir a reedição de MPs foi dada em 1990 na ADI 295, em que o Conselho Federal da Ordem dos Advogados contestava a constitucionalidade da MP 186, que impedia a concessão de medidas liminares de tribunais de primeira e segunda instância contra o plano de estabilização da moeda apresentado pelo então presidente Fernando Collor de Melo ${ }^{18}$. Na ADI, o Conselho pediu “a inadmissibilidade da reiteração de Medidas Provisórias" - já que a MP 186 havia sido reeditada quatro vezes e sustentou que "se o Poder Legislativo já deixou de apreciar a medida provisória, significa que entendeu inexistente[s] os motivos previstos no artigo 62 da Constituição Federal e, pois, não há condições fáticas ou empíricas para sua reiteração" (BRASIL, 1997). Em sua decisão, o STF firmou o entendimento de que as MPs não rejeitadas pelo Congresso poderiam ser reeditadas. O Ministro Paulo Brossard foi o único voto vencido, no qual

\footnotetext{
17 Sobre o papel do Legislativo na primeira reedição de medida provisória ver Caliman (2003) e Oliveira (2009).

18 Para uma análise do papel do STF nesse caso em particular e na redefinição dos poderes presidenciais pós 1988 ver Arguelhes (2014).
} 
argumentou que, diferentemente do Decreto-Lei, a não apreciação de uma MP pelo Legislativo no prazo definido por lei, não significava uma aprovação tácita. $\mathrm{O}$ Ministro disse ainda que uma MP poderia ser rejeitada de duas formas: por meio da sua rejeição formal ou tácita, que seria por decurso de prazo. Uma Medida formalmente rejeitada não poderia ser reeditada, como já havia decidido o STF na ADI 293 (BRASIL, 1993). Mas, segundo Brossard, a rejeição tácita teria o mesmo efeito que a formal, a caducidade da MP, e, por isso, também não poderia ser reeditada. Ou seja, Brossard defendeu a interpretação que Cardoso havia feito no Congresso um ano antes e que havia sido rejeitada pelo parecer de Jobim. O argumento de Brossard, contudo, foi rejeitado logo no voto seguinte, proferido pelo ministro Marco Aurélio que disse que "não há no artigo 62 qualquer preceito, qualquer expressão que obstaculize a reedição de Medidas Provisórias" (BRASIL, 1997). Os demais Ministros também discordaram dos argumentos elaborados por Brossard e não viram impedimento na reedição de MPs que não tivessem sido apreciadas pelo Congresso.

À primeira vista, a possibilidade de reeditar MPs significa de fato um aumento do poder de agenda do Executivo. Isso porque o governo não precisaria necessariamente reunir maioria no congresso para aprovar suas Medidas, tendo apenas que evitar que o Congresso deliberasse de forma contrária, rejeitando a MP (FIGUEIREDO; LIMONGI, 1999). Nesse caso, portanto, o Executivo teria a possibilidade de alterar e manter alterado o status quo por tempo indeterminado praticamente sem atores capazes de vetar sua política pública. No entanto, isso não deve ser visto como uma total abdicação de poderes ao Executivo, mas sim uma delegação estratégica, sendo do interesse do próprio Congresso (FIGUEIREDO; LIMONGI, 1999). Segundo Pires (2008), baseado em depoimento de Nelson Jobim (2007), haveria pelo menos três motivos políticos para o silêncio do Congresso no que se refere às MPs: evitar se envolver em matérias polêmicas e impopulares e, com isso, deixar todo ônus de um possível fracasso ao Executivo; e o uso estratégico pela maioria parlamentar para, por meio das reedições, negociar alterações no texto original de acordo com seus interesses. Em outras palavras, a reedição de MPs com alterações seria um instrumento de barganha entre os dois Poderes.

Pode-se concluir que este desenho institucional de tramitação de MPs não previsto na Constituição foi inicialmente fruto de uma espécie de conversion implementada pelo Executivo e aceita, sem formalização, pelo Legislativo. O STF foi fundamental para dar a palavra final permitindo a reedição de MPs. Esse desenho conferia ao Executivo forte poder de agenda, permitindo a alteração do status quo de forma permanente praticamente sem a interferência do Legislativo como ator de veto. Além disso, proporcionava ao Presidente um recurso de coordenação e negociação importante com o Congresso, principalmente com os partidos de sua coalizão ao permitir a reedição de MPs com alterações. Os parlamentares, por sua vez, se protegiam de assumir posições em temas controversos e ainda podiam incluir temas de seus interesses nas negociações em 
torno da reedição. Assim, podiam usar as MPs para implementar medidas de seus interesses sem passar por todo o trâmite legislativo exigido por projetos de lei, por exemplo. Nessa configuração, os atores que mais perdiam com a reedição de MPs eram os parlamentares de oposição, que praticamente não tinham como vetar uma proposta encaminhada pelo Executivo, nem forçar a base de governo a se pronunciar sobre temas polêmicos. Foi justamente a insatisfação da oposição com esse desenho que provocou uma mudança importante na tramitação das MPs implementada pela EC 32: o sobrestamento de pauta.

\section{Sobrestamento de pauta}

A EC 32 incluiu o sobrestamento da pauta no processo decisório da MP. Com isso, o Congresso Nacional passaria a ser obrigado a votar as medidas provisórias, em um prazo relativamente curto, sob o risco de ter paralisadas suas atividades legislativas (artigo 62, parágrafo $6^{\circ}, \mathrm{CF}$ ). Se a medida pode ser concebida, por um lado, como uma forma do Congresso retomar certo protagonismo legislativo, por outro, dada a regra de trancamento, significa ter que assumir posições públicas a respeito de temas muitas vezes controversos e ter sua agenda interna em grande medida definida pelo Executivo. Por que aprovar uma Emenda que aparentemente aumentaria os custos para o próprio Congresso? O sobrestamento não constava do desenho institucional originalmente concebido pelo Congresso para alterar o artigo 62. As discussões travadas no Congresso a respeito da tramitação da PEC 32 revelam que a ideia de sobrestar a pauta foi uma reivindicação da oposição. Os objetivos da oposição eram obrigar o Congresso votar as medidas provisórias para expor a maioria governista à obrigação de ter que justificar seu posicionamento e poder participar da apreciação das medidas. Como diversas medidas provisórias tratam de temas controversos e impopulares, a avaliação da oposição era que, por um lado, a não votação das MPs livrava a maioria de não assumir os ônus das medidas propostas pelo Executivo e, por outro, se configurava como uma espécie de obstrução à sua própria ação.

A proposta de sobrestamento foi incluída por reivindicação da oposição e não foi retirada ao que tudo indica pelo fato dos próprios parlamentares não se darem conta de que o prazo estipulado para o sobrestamento poderia ser um problema (Pires, 2008). Esperava-se que a medida limitasse o uso de medidas provisórias editadas pelo Executivo. Entretanto, não houve diminuição no número de edição de MPs pelo Executivo, o que ocasionou uma paralisação constante das atividades legislativas dada a obrigatoriedade de deliberação. Aparentemente, a nova regra conferiu ainda mais poder de agenda ao Executivo, na medida em que a pauta do Legislativo passa a ser controlada pela votação das MPs. Nesse sentido, as MPs funcionam como instrumento de barganha nas negociações partidárias. $O$ presidente já não precisa do apoio dos líderes para definir a agenda". (MACHIAVELI, 2009). 
Essa situação provocou uma reação dos parlamentares que passaram a questionar o alcance do sobrestamento nas deliberações do Congresso. Para se ter uma ideia, uma consulta sobre questões de ordem filtrada com o termo "art. 62" na página da Câmara dos Deputados retorna 202 resultados. Observa-se que imediatamente após a EC 32, há um aumento expressivo da quantidade de questões de ordem que citam o artigo 62 da Constituição.

\section{Gráfico 1 - Número de Questões de Ordem que citam o artgo 62 da Constituição Federal entre 2001 e 2018}

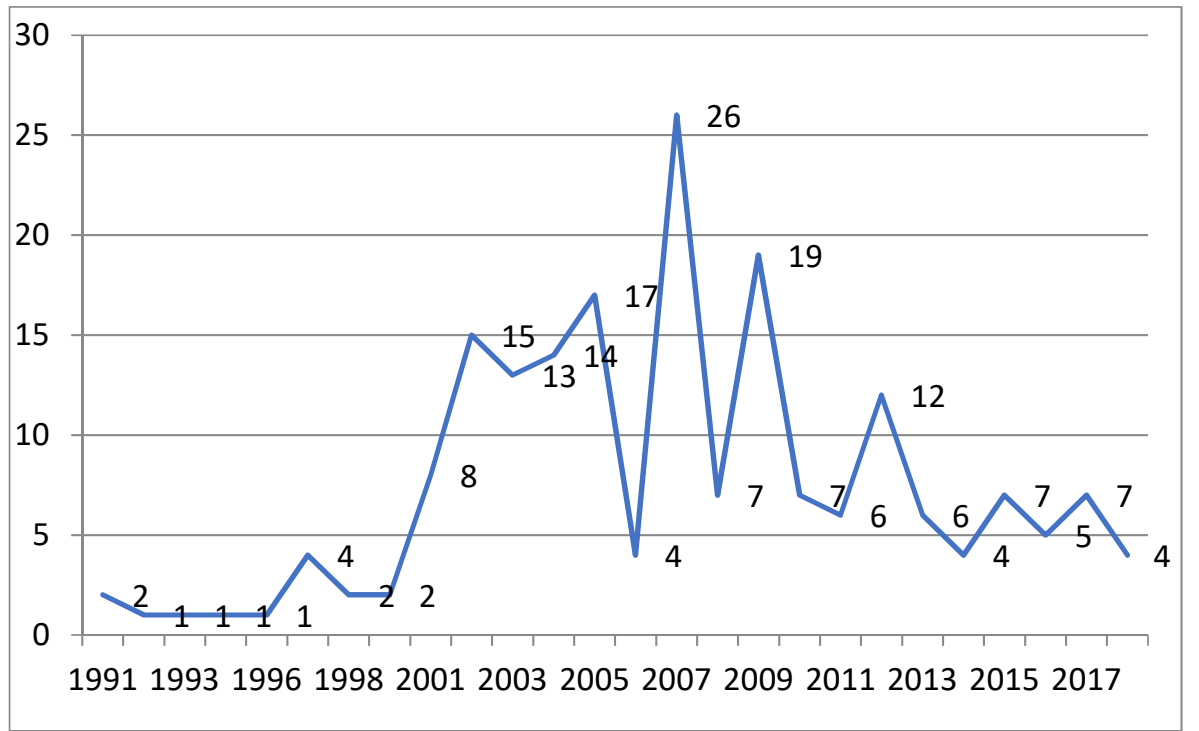

Fonte: Elaborado pelo autor a partir da busca na Câmara dos Deputados

Já em 2002, a Questão de Ordem 688 (BRASIL, 2002) questiona se as pautas das Comissões também estariam submetidas ao sobrestamento em caso de não apreciação de MP no prazo de 45 dias. A questão foi indeferida pelo então presidente da Câmara dos Deputados, Aécio Neves, afirmando-se que apenas o Plenário da Câmara, órgão responsável pela apreciação das medidas provisórias estaria sujeito ao trancamento. Ao fundamentar sua decisão, Aécio Neves argumenta sobre a necessidade de se superar uma leitura literal das normas por meio da sua interpretação teleológica ou sistemática. Firmando-se numa interpretação a respeito da verdadeira finalidade das novas regras de tramitação das MPs, Neves sustenta que "Ao sustar todas as deliberações da Casa Legislativa, o texto constitucional busca, na verdade, que a votação da medida provisória seja efetuada imediatamente pelo órgão responsável pela sua apreciação, no caso, o Plenário da Câmara dos Deputados, sem que seja preterida por qualquer outra deliberação deste mesmo Plenário" (BRASIL, 2002).

A interpretação teleológica foi usada posteriormente na interpretação do termo "deliberações legislativas" que estariam sujeitas ao sobrestamento pela nova 
redação dada ao texto constitucional pela EC 32. Na Questão de Ordem 536 (BRASIL, 2005), em 2005, o então Deputado José Carlos Aleluia pergunta se a votação do processo de cassação do mandato do Deputado André Luiz e a escolha de dois representantes do Legislativo para o TCU estariam sobrestados, já que uma MP estaria trancando a pauta do Plenário. A resposta produzida por essa QO definiu que "deliberações legislativas" são aqueles em que "a regra do $\S 6^{\circ}$ do artigo 62 deva ser aplicada apenas aos atos de deliberação em procedimentos destinados ao exercício da função legislativa e não a toda e qualquer deliberação adotada pelas Casas do Congresso Nacional" (BRASIL, 2005). Essa interpretação foi reafirmada na Questão de Ordem 539, em 2005 (confirma a interpretação de que cassação de mandato não é deliberação legislativa). Em 2007, na Questão de Ordem 56, o deputado Onyx Lorenzoni questiona se "se recurso oferecido contra a instauração de procedimento de fiscalização do Poder Executivo constitui atividade típica ou atípica do Poder Legislativo" (BRASIL, 2007), argumentando que deveria sim ser considerado uma deliberação legislativa. Sua opinião foi contradita pelo deputado Henrique Fontana que, invocando o artigo 59 da Constituição, elenca como atividades do processo legislativo a elaboração de emendas à Constituição, leis complementares, leis ordinárias, leis delegadas, medidas provisórias, decretos legislativos e resoluções. Ao responder a essa questão, o então presidente da Câmara Arlindo Chinaglia indefere o pedido de Lorenzoni e reforça o entendimento de que deliberações legislativas são aqueles destinadas à elaboração de normas gerais e abstratas e acrescenta que "A previsão de sobrestamento garante, assim, a primazia na apreciação das medidas provisórias sobre todas as espécies legislativas contempladas no art. 59 da Constituição Federal, inclusive sobre os projetos de lei do Presidente da República com solicitação de urgência, nos termos do art. 64, $\S 2^{\circ}$ do texto constitucional" (BRASIL, 2007), com exceção de decretos legislativos e resoluções - que já haviam sido excluídos de QOs anteriores.

A grande inovação institucional no que se refere ao sobrestamento foi produzida pela interpretação do então Presidente da Câmara, Michel Temer, à Questão de Ordem 411 em 2009. O Deputado Regis de Oliveira questiona se todos os itens do artigo 59, as resoluções, realmente estão sujeitos ao trancamento de pauta. Em sua formulação, Oliveira argumenta que todos os atos normativos previstos no artigo 59 podem ser compreendidos como "deliberações legislativas", excetuando-se as resoluções e, por isso, "quando da medida provisória trancar a pauta de deliberações da Câmara dos Deputados, não há tal providência em relação às resoluções, que prosseguem sua tramitação normal, inclusive inclusão na ordem do dia do Plenário, sem qualquer restrição" (BRASIL, 2009).

Ao responder essa Questão de Ordem, Michel Temer afirma que "além das resoluções, que podem ser votadas apesar do trancamento da pauta por uma medida provisória, também assim pode ocorrer com as emendas à Constituição, com a lei complementar, com os decretos legislativos e, naturalmente, com as resoluções." Diz ainda que responderia à questão para que os argumentos 
apresentados que fundamentam essa decisão constem das notas taquigráficas para "objeto de contestação, contestação da mais variada natureza, mesmo de ordem judicial." Temer organiza sua fundamentação em duas grandes dimensões: uma política e outra jurídica. $\mathrm{O}$ aspecto político ressaltado por ele tem a ver com a constante paralisação dos trabalhos da Câmara por causa do sobrestamento de pauta provocado pelas MPs.

Sua fundamentação jurídica se apoia na divisão das funções primordiais de cada poder, Executivo, Legislativo e Judiciário. A atividade legislativa deveria ser exercida primordialmente pelo Legislativo, cabendo exceções, como é o caso do exercício legislativo realizado pelo Executivo por meio das medidas provisórias. Acrescenta que "toda vez que há uma exceção esta interpretação não pode ser ampliativa. Ao contrário. A interpretação é restritiva. Toda e qualquer exceção retirante de uma parcela de poder de um dos órgãos de Governo, de um dos órgãos de poder, para outro órgão de Governo só pode ser interpretada restritivamente." A questão então seria entender, a partir dessa premissa restritiva, como interpretar o termo "deliberação legislativa" dado pela nova redação do artigo 62. Ao responder essa indagação, Temer se apoia em outra premissa, a de que a interpretação do texto constitucional deve ser uma interpretação sistêmica, entendida por Temer como a intepretação que "encaixa" o dispositivo constitucional ao "sistema" da ordem jurídica brasileira. Assim, a argumentação teleológica que sustentava a interpretação a respeito do sobrestamento até aquele momento dá lugar a uma nova intepretação.

A interpretação de Michel Temer foi interpelada no STF em mandado de segurança preventivo com pedido de liminar (BRASIL, 2015). O relator do caso foi o ministro Celso de Melo que indeferiu o pedido e sustentou a interpretação sistêmica dada por Temer dado o conteúdo polissêmico do termo "deliberações legislativas". De forma breve, o Ministro afirmou que havia uma edição compulsiva de MPs pelo Executivo, levando ao trancamento sistemático da pauta das Casas Legislativas e a uma perda do poder de agenda do Legislativo. A conjugação de tais fatores teria levado a um Poder Executivo hipertrofiado em comparação ao Legislativo, ferindo a separação dos poderes (artigo $2^{\circ}$, CF/88). A solução seria, portanto, o afastamento de interpretações contrárias à Constituição.

Em 2017, 8 anos após o indeferimento da cautelar, o Plenário denegou o Mandado de Segurança. O único Ministro que divergiu do Relator foi o Marco Aurélio, que afirmou que o dispositivo constitucional seria claro, devendo ser interpretado de forma literal (BRASIL, 2017). A nova interpretação do parágrafo $6^{0}$ do artigo 62 foi um caso de imaginação política realizada através de conversion. Embora a expressão "todas as demais deliberações legislativas" não pareça ser ambígua ou vaga, sugerindo um caso de transgressão, e não de imaginação política, diversas interpretações rodearam o dispositivo. Não foi um caso no qual os parlamentares decidiram simplesmente ignorar a regra existente, mas sim sugerir diferentes interpretações de um termo que - na sua visão - é controverso, haja vista 
não haver uma certeza quanto ao que pode ser incluído em "deliberações legislativas". Formalmente, a regra do parágrafo permaneceu, mas houve - ao longo do tempo - diversas mudanças em sua aplicação, sendo a última e mais importante, a interpretação de Michel Temer referendada pelo STF.

Se antes o Congresso era obrigado a deliberar sobre MPs sob pena de ter sua pauta trancada, o entendimento de Michel Temer pode ser visto como extremamente vantajoso para o Congresso, já que devolveu sua capacidade de organização da agenda interna. $\mathrm{O}$ entendimento aumentou os custos de edição de MPs em excesso pelo Executivo, tendo em vista que diminuiu os custos para o Congresso de não deliberar. Se o Presidente da República enviar muitas MPs - o Congresso pode decidir simplesmente não deliberar a respeito sem que isso seja custoso para o órgão, já que sua pauta não é mais trancada. Isso também é positivo para o Congresso na medida em que não há necessidade de deliberar sobre temas controversos e acentuado pela falta de necessidade de edição de decreto legislativo para reger as relações estabelecidas no período de vigência da MP que perdeu eficácia (artigo 62, parágrafo 11, CF).

Deve-se ter em mente que não foram apenas o Legislativo e, mais especificamente, o então Presidente da Câmara, Michel Temer, os únicos vencedores com a denegação do MS. A decisão do STF tem um caráter dual, já que - ao mesmo tempo que confirma o entendimento de Temer - também expande os Poderes da própria Corte (ARGUELHES, 2009). Isso acontece, pois - ao afirmar o caráter constitucional da questão - o STF estabeleceu que seria da Corte a palavra

final sobre as interpretações feitas por parlamentares quanto às regras do próprio Legislativo. Assim, qualquer interpretação realizada, para ser considerada válida, deveria passar pelo crivo da Corte.

\section{Comissões}

A EC 32 havia definido em seu artigo 9o que, antes de serem apreciadas pelo Plenário de cada Casa do Congresso Nacional, uma Comissão Mista formada por deputados e senadores deveria ser instalada para examiná-las ${ }^{19}$. Observa-se que, originalmente, a Resolução 1 do Congresso Nacional editada em 2002 determinou, em seu artigo 5, que a Comissão Mista teria um prazo improrrogável de quatorze dias, a partir da publicação da MP no Diário Oficial da União para emitir seu

\footnotetext{
${ }_{19}$ Segundo o artigo $2^{\circ}$ da Resolução 1 de 2002 que dispõe sobre a apreciação de MPs pelo Congresso Nacional a composição da Comissão Mista deve obedecer as seguintes regras: "§ 2º A Comissão Mista será integrada por 12 (doze) Senadores e 12 (doze) Deputados e igual número de suplentes, indicados pelos respectivos Líderes, obedecida, tanto quanto possível, a proporcionalidade dos partidos ou blocos parlamentares em cada Casa." $\S 3^{\circ}$ O número de membros da Comissão Mista estabelecido no $\S 2^{\circ}$ é acrescido de mais uma vaga na composição destinada a cada uma das Casas do Congresso Nacional, que será preenchida em rodízio, exclusivamente, pelas bancadas minoritárias que não alcancem, no cálculo da proporcionalidade partidária, número suficiente para participar da Comissão."
} 
parecer e seu artigo 6 $\S^{\circ}$ que "Esgotado o prazo previsto no caput do art. 5o, o processo será encaminhado à Câmara dos Deputados, que passará a examinar a Medida Provisória" ${ }^{20}$. O efeito dessa resolução, que adicionou uma regra não prevista na EC 32, foi que, praticamente, as Comissões não foram implementadas. $\mathrm{Na}$ verdade, essa regra permitiu que as MPs fossem encaminhadas diretamente à Câmara quando esgotado o prazo de quatorze dias, aparentemente diminuindo a possibilidade de manifestação do Legislativo, principalmente eventuais posicionamentos contrários da oposição.

As Comissões Mistas só passaram a ser realmente instaladas a partir de uma decisão do STF, na ADI 4029 de 2012, que julgou inconstitucionais os artigos 5o e $6^{\circ}$ da Resolução. A ação, ajuizada pela Associação Nacional dos Servidores do Ibama (Asibama Nacional), questionava a constitucionalidade da Lei Federal 11.516/07 que criou o Instituo Chico Mendes de Conservação da Biodiversidade (ICMBio). A Asibama Nacional apresentou argumentos materiais e formais para a declaração de inconstitucionalidade. Dentre os argumentos formais alegou-se que a referida Lei foi o resultado da conversão de uma da MP 366 que não havia sido examinada por uma Comissão Mista no Congresso Nacional, tal como determina o artigo 62 (BRASIL, 2012). O Senado Federal, por sua vez, se manifestou citando uma decisão do STF na ADI 3289/2005 contra a MP 207/2004 em que o relator, Ministro Gilmar Mendes, considerou que a não instalação de uma Comissão Mista para analisar a MP em questão não era uma ofensa ao artigo 62.

O STF julgou improcedente a ação, mas com declaração incidental de inconstitucionalidade dos artigos 5 e 6 da Resolução 01/2002. Em seu voto, o relator, Ministro Luiz Fux, afirmou que a Constituição Brasileira não permite "a dispensabilidade do parecer da Comissão Bicameral" na avaliação de medidas provisórias, o que, segundo ele, "põe em cheque...a própria constitucionalidade do processo legislativo" afirmados nos artigos 5 e 6 da Resolução (BRASIL, 2012, p. 08). Argumentou ainda que a instauração da comissão mista não era uma mera formalidade, mas sim "uma garantia de que o Legislativo seja efetivamente o fiscal do exercício atípico da função legiferante do Executivo" (BRASIL, 2012, p. 09). Ao afirmar esse posicionamento, Fux alegou que a decisão anterior proferida pelo ministro Gilmar Mendes na ADI 3289 tinha "motivos circunstanciais", já que Mendes sustentou - naquele momento - o Congresso estava "em uma fase de consolidação de um novo modelo trazido pela Emenda 32" (BRASIL,2012, 0.09).

${ }^{20}$ A Comissão terá prazo improrrogável de 14 dias, contado da publicação da Medida Provisória no Diário Oficial da União para emitir parecer único, manifestando-se sobre a matéria, em itens separados, quanto aos aspectos constitucional, inclusive sobre os pressupostos de relevância e urgência, de mérito, de adequação financeira e orçamentária e sobre o cumprimento da exigência prevista no $\S 1$ do art.2Artigo $6 \S 1^{\mathrm{o}}$ “Esgotado o prazo previsto no caput do art. 5o, o processo será encaminhado à Câmara dos Deputados, que passará a examinar a Medida Provisória" Art. 5 e $6^{0}$ declarados inconstitucionais, em controle concentrado, pelo Supremo Tribunal Federal, pela ADIN no 4.029, publicada no DOU de 16/3/2012). 
Proferido o voto do relator, o Ministro Gilmar Mendes se manifestou e afirmou que, até o momento, o instituto da medida provisória não tinha sido realmente disciplinado. Segundo Fux, este argumento "soaria frívolo" passados dez anos da promulgação da EC 32 (BRASIL, 2002 p.20) e afirma, posteriormente, que a "A efetividade do art. 62, §9, da Carga Magna não pode mais ser negada" (BRASIL, 2012 p.22). Lewandowski divergiu dos demais ministros ao sustentar que a Resolução tratava de uma matéria interna corporis "e o Supremo Tribunal Federal, em mais de uma decisão, diz que nós não podemos nos debruçar sobre matéria desta natureza" (BRASIL, 2012, p. 60). Argumentou também que a obrigação de instalação de comissão acabaria por permitir obstruções no processo legislativo, o que retiraria o poder do Executivo em tomar medidas tempestivas ${ }^{21}$.

A Comissão Mista confere ao Legislativo a possibilidade de aprovar totalmente a MP editada pelo Executivo, alterar a proposta da MP (convertendo-a um Projeto de Lei de Conversão) ou rejeitar a MP, enviando sua apreciação ao Plenário. Além disso, o presidente da Comissão pode indeferir liminarmente as emendas estranhas ao texto original da MP apresentadas pelos parlamentares. Nesse sentido, é um espaço institucional importante para a atuação dos parlamentares na tramitação de MPs. Se uma MP tiver que passar por uma Comissão é provável que o Executivo tenha que contemplar as escolhas possíveis de sua atuação em seus cálculos. A Resolução 1 de 2002 permitia que essa etapa da tramitação fosse evitada, prática que se tornou comum na edição de MPs até a decisão do STF que formalizou sua obrigatoriedade, o que pode significar um poder de agenda maior do Executivo. A base parlamentar do governo, evitando a Comissão, se livrava de ter que se posicionar em eventuais temas polêmicos e a oposição se encontrava em uma situação não poder exercer nenhum tipo de veto à MP proposta. Por meio de uma regra adicionada pelo Resolução 1, portanto, uma instância de interação importante com o Legislativo podia ser evitada. A decisão do STF foi fundamental, portanto, para incluir o Legislativo no processo decisório da tramitação das MPs.

A decisão proferida na ADI 4029 suscitou novas interpretações para o momento de contagem do prazo para o sobrestamento da pauta. No dia 19 de junho de 2012, o então presidente da Câmara dos Deputados, Marco Maia, diante da necessidade se se imprimir o rito de tramitação de MPs definido na ADI 4029, decidiu que "o trâmite da medida provisória nesta Casa inicia-se a partir da publicação da

${ }^{21}$ Cf. Peluzzo (BRASIL, 2012 p. 69), “[n]o caso concreto, tampouco vejo, com o devido respeito, como alguma coisa anômala ou atípica a previsão de prazo para a atuação de comissão prevista na Constituição. O que o Congresso Nacional fez? Estabeleceu um prazo para forçar que a comissão atue. Porque, doutro modo, pensando-se que o Congresso não possa fazê-lo, temos o quê? Temos que essa comissão não se sentirá obrigada, em nenhum instante, a manifestar-se, e vai se escoar o prazo após o qual a medida provisória perde a eficácia. Noutras palavras, é método de operacionalidade do próprio Legislativo. Se o Legislativo não estabelece esse prazo, a comissão evidentemente não se sentirá de nenhum modo movida a exercer a competência que a Constituição lhe atribui". 
matéria" (BRASIL, 2012)22. Segundo Maia, enquanto uma MP estiver na Comissão Mista ela não tranca a pauta, por não estar tramitando na Câmara (BRASIL, 2012). Por essa interpretação do regimento, portanto, as MPs passaram a trancar somente depois de passar nas Comissões (NEVES, 20112). Em 2014, o deputado Eduardo Cunha, na Questão de Ordem 394 (BRASIL, 2014), argumentou haver uma diferenciação no tratamento dado à tramitação de MPs no Senado e na Câmara. Segundo o deputado, enquanto na Câmara, o trancamento de pauta ocorreria após concluída a apreciação da Comissão Mista, no Senado a pauta só era trancada após a leitura da MP em Plenário. Propôs, então, que “... a Câmara deveria adotar o mesmo procedimento. V. Exa. deveria ler a medida provisória e dar o prazo de 48 horas para que a Casa tomasse conhecimento. Só a partir da leitura haveria o trancamento de pauta, e só votaríamos após as 48 horas"(BRASIL, 2014). ${ }^{23}$ O então presidente, Henrique Eduardo Alves não acatou da mudança proposta por Eduardo Cunha, o que só foi ocorrer no ano seguinte, no dia 07 de abril e 2015, quando ele, como presidente da Câmara deferiu um pedido semelhante feito pelo então Deputado Leonardo Picciani na Questão de Ordem 43 (BRASIL, 2015).

No dia 9 de abril, os Deputados Sibá Machado e Alessandro Molon ingressaram com um mandado de segurança no STF (BRASIL, 2015), com pedido de liminar, contra a decisão tomada por Cunha de instaurar uma sessão para a votação do PL 4330. O embate se deu justamente pela interpretação a respeito do trancamento de pauta. No entendimento de Machado e Molon, a pauta estaria trancada para a

22 "Existem pelo menos dois motivos determinantes para que, diante dessas circunstâncias, o chamado trancamento da pauta só ocorra efetivamente a partir do momento em que a medida provisória inicia sua tramitação na Câmara. O primeiro tem a ver com a enfática dicção do texto constitucional, ao estabelecer que a medida provisória sobrestará a pauta da "Casa em que estiver tramitando". Portanto, ao estar no Congresso Nacional e numa Comissão Mista, ela não está tramitando nem Câmara nem no Senado, senão, por consequência, ela teria de trancar a pauta das duas Casas ao mesmo tempo. O segundo refere-se à própria natureza do instituto previsto no art. $62, \S 6^{o}$, da Constituição. Diante da impossibilidade de impor taxativamente que um órgão colegiado do Poder Legislativo se reúna e delibere, a figura do sobrestamento procura criar uma situação que estimule a tomada de decisão. Para tanto, impede - salvo exceções que decorrem da própria Constituição - que um órgão cuja pauta se encontra sobrestada se ocupe de qualquer matéria estranha à que foi priorizada pela Constituição até que se desincumba dos afazeres legislativos a ela pertinentes."

${ }^{23}$ Concluiu o Plenário daquela Suprema Corte que, a despeito de o PLC n. 101/2003 ter sido aprovado pelo Senado Federal antes de deliberar sobre as citadas medidas provisórias, o processo legislativo do qual resultara a Lei Federal n. 10.828/2003 não padecia do vício de inconstitucionalidade formal, visto que os dois dias que intermediaram o recebimento das medidas provisórias e a sessão em que deliberadas não configuraram abuso do processo legislativo, mas lapso razoável e adequado de preparação para a discussão e a votação das matérias. Somou-se ao fundamento dessa decisão judicial o fato de as medidas provisórias terem sido votadas, embora em momento posterior, na mesma sessão em que aprovado o PLC n. 101/2003, o que evidenciou a ausência de manipulação do processo legislativo neste caso. 
apreciação da MP 661, enquanto Cunha alegou que o sobrestamento estaria subordinado à leitura da MP no Plenário. O pedido de liminar foi indeferido pelo ministro Gilmar Mendes em dezembro de 2015. O Ministro destacou, em sua decisão, que o ordenamento jurídico não prevê um momento exato para o sobrestamento de pauta do Congresso e que no julgamento da ADI 3146 (BRASIL, 2006) o STF, embora não tenha entrado no tema por entender se tratar de assunto interna corporis, entendeu que entre o recebimento e a votação da MP em Plenário é possível haver deliberações legislativas, "desde que não se configure abuso ou desproporcionalidade". Essa decisão foi reafirmada na decisão monocrática publicada por Mendes em fevereiro de 2019. Essa interpretação final para o início da contagem de prazo para o sobrestamento de pauta, formalizada pelo STF, conferiu à Câmara um espaço de tempo maior, mesmo que curto, para tomada de decisões legislativas.

\section{Jabutis (emendas com impertinência temática e medidas provisórias)}

A Emenda Constitucional no 32, promulgada em 2001, é mais conhecida pela vedação de reedição de medidas provisórias pelo Presidente da República. A Emenda, entretanto, alterou importantes os poderes de agenda e veto dos Poderes Legislativo e Executivo. O parágrafo 12 da referida Emenda concedeu aos parlamentares a prerrogativa de alterar o texto original de medidas provisórias seja excluindo, adicionando ou modificando o projeto. Tal prerrogativa iniciou o costume da inserção em medidas provisórias de "Jabutis", - nome dado às emendas parlamentares sem afinidade ou conexão material em relação ao texto original editado pelo Chefe do Executivo. Vale destacar que a prática de inclusão de Jabutis já era realizada em outros projetos de lei, havendo - inclusive - regras proibindo tal prática, como o artigo $7^{0}$ da Lei Complementar 95/1998 ${ }^{24}$ e o artigo $4^{\circ}$, parágrafo $4^{\mathrm{o}}$ da Resolução $\mathrm{n}^{\circ} 1$ de $2002^{25}$ do Congresso Nacional. Assim, o costume seria uma clara violação de regras já existentes, não somente um caso de criatividade política. A ADI 5.12726, proibiu a prática de "inserção [...] de matérias de conteúdo temático

\footnotetext{
24 “Art. $7^{\circ} \mathrm{O}$ primeiro artigo do texto indicará o objeto da lei e o respectivo âmbito de aplicação, observados os seguintes princípios: II - a lei não conterá matéria estranha a seu objeto ou a este não vinculada por afinidade, pertinência ou conexão;"

${ }^{25}$ Art. $4^{\mathrm{o}}$ Nos 6 (seis) primeiros dias que se seguirem à publicação da Medida Provisória no Diário Oficial da União, poderão a ela ser oferecidas emendas, que deverão ser protocolizadas na Secretaria-Geral da Mesa do Senado Federal. § $4^{\circ}$ É vedada a apresentação de emendas que versem sobre matéria estranha àquela tratada na Medida Provisória, cabendo ao Presidente da Comissão o seu indeferimento liminar.

${ }^{26}$ A ADI 5.127 foi proposta pela Confederação Nacional das Profissões Liberais contra o artigo 76 da Lei no 12.249/2010, incluído nela por meio de uma emenda parlamentar ao projeto de conversão da Medida Provisória no 472/2009. A ADI foi julgada improcedente, mas o STF firmou o entendimento, ex nunc, de que não é compatível com a $\mathrm{CF} / 88$ a apresentação de emendas sem pertinência temática com o objeto da medida provisória.
} 
estranho ao objeto originário da $\mathrm{MP}^{\prime \prime}$, afirmando o caráter constitucional da questão, e sujeitando as emendas ao controle jurisdicional prévio do Supremo Tribunal Federal. Embora a transgressão das regras já tivesse sido questionada algumas vezes antes da ADI 5.127, tudo para aponta para a ideia de que a inserção de jabutis era algo benéfico para grande parte dos membros do Legislativo e, inclusive, para o Executivo. A inserção de jabutis era sistemática, enquanto os questionamentos eram raros.

A possibilidade de emendar MPs foi uma forma encontrada pelo Congresso para evitar situações do tipo "pegar ou largar" a proposta do executivo (Cunha 2012), já que conferiu aos parlamentares a possibilidade de retirar, alterar ou adicionar artigos. Antes da EC 32, havia a possibilidade de reedição das MPs com alterações, o que permitia a barganha entre os Poderes. Assim, a EC 32 manteve tal possibilidade de negociação, desta vez sob a inserção de emendas parlamentares. Assim, poder-se-ia afirmar que a possibilidade de emendar medidas provisórias se não aumentou, pelo menos manteve, os poderes de agenda e de veto do Congresso Nacional. Os parlamentares poderiam, a partir de então, fazer alterações nas medidas provisórias propostas pelo Chefe do Executivo de acordo com seus interesses.

Como apontado anteriormente, a inserção de jabutis era uma prática frequente também em outros projetos de lei iniciados pelo Executivo que não medidas provisórias. Portanto, a prática é mais antiga do que a Emenda Constitucional $\mathrm{n}^{\circ}$ 32. A ADI $1.050^{27}$, julgada em 1994, já havia vedado a possibilidade de inserção de emendas parlamentares em projetos do Executivo sem conexão temática com a iniciativa normativa original. A decisão foi reiterada por diversas outras, de modo que houvesse uma "jurisprudência pacífica" no STF acerca da impossibilidade de inserção de jabutis em projetos de lei iniciados pelo Poder Executivo.

Além das diversas decisões do Supremo Tribunal Federal que proibiam a inserção de Jabutis, a Lei Complementar no 95 de 1998, que dispõe sobre a "elaboração, a redação, a alteração e a consolidação das leis" (artigo $1^{\circ}$ ) já estabelecia que a lei não poderia conter "matéria estranha a seu objeto ou a este não vinculada por afinidade, pertinência ou conexão" (artigo 7º , II) antes mesmo da promulgação da Emenda de 2001. Havia, ainda, o Regimento Interno da Câmara dos Deputados, que determina que "nenhuma proposição poderá conter matéria estranha ao enunciado [...]" (artigo 100, p. 30). Compreende-se, portanto, que embora já existissem vedações à inserção de jabutis em projetos de lei quando a Emenda Constitucional $\mathrm{n}^{\circ} 32$ foi promulgada, os congressistas ignoravam tais disposições no que diz respeito às medidas provisórias.

\footnotetext{
${ }^{27}$ A ADI 1.050, cujo relator foi o Ministro Celso de Mello, firmou o entendimento de que o poder de emendar projetos de lei é uma prerrogativa inerente ao exercício da atividade legislativa, mas que tem certas limitações, dentre as quais se encontra guardar afinidade lógica (relação de pertinência) com a proposição original.
} 
Vale ressaltar, entretanto, que a Resolução ${ }^{\circ} 1$ do Congresso Nacional, de 2002, já havia vetado a apresentação de jabutis especificamente no caso de medidas provisórias, sob pena de indeferimento liminar do Presidente da Comissão (artigo $4^{\circ}$, parágrafo $4^{\circ}$ ). A Resolução de 2002 é importante, pois mostra que o caso de inserção de jabutis em medidas provisórias não é um mero caso de imaginação política, mas sim de transgressão de regras. Não se trataria, assim, de um caso no qual os agentes políticos reinterpretam informalmente as regras vigentes, mas sim de transgressão sistemática de regras, tendo em vista que a prática era claramente e expressamente vedada pelas normas mencionadas vigentes. Assim, formalmente as regras permaneciam, mas os parlamentares as negligenciavam, configurando um caso de drift.

Não parece haver casos de questionamento sobre a inclusão de jabutis em medidas provisórias, com exceção da até a formulação da Questão de Ordem $352^{28}$. Isso parece indicar que a inclusão de emendas sem pertinência temática deveria beneficiar quase todos, ou pelo menos a grande maioria, dos parlamentares. Até mesmo o Executivo, que - à primeira vista - pensar-se-ia prejudicado pela inserção de jabutis, parecia estar de acordo com o costume.

Na Questão de Ordem 352, levantada pelo Deputado Miro Teixeira, o então Presidente da Câmara, Deputado Henrique Eduardo Alves, decidiu que medidas provisórias, emendas ou projetos de lei de conversão que contivessem matéria estranha ao enunciado deveriam retornar à comissão mista "para as devidas adequações". Essa Questão de Ordem teria sido um primeiro desincentivo à inserção de Jabutis (SOUSA, 2015). Entretanto, como apontado por Cesar van der Laan (2018), Eduardo Cunha, como Presidente da Câmara em 2015, entendeu que "não caberia ao presidente da Câmara dos Deputados elaborar juízo de valor sobre parecer aprovado pela Comissão Mista, ainda que contivesse matéria estranha ao objeto da MP originalmente editada". Essa decisão parece ter enfraquecido o poder de veto do Presidente da Comissão e aumentado o poder de agenda de cada um dos membros da comissão mista. Em outras palavras, os parlamentares da Comissão poderiam incluir emendas impertinentes com maior facilidade, já que o Presidente da Comissão não poderia mais evitar a inserção de jabutis a partir de juízos negativos dos pareceres, implicando um retrocesso na questão dos jabutis.

Não há como apontar, ao certo, a razão pela qual o Poder Executivo seria a favor da prática, posicionamento evidenciado a partir da declaração do Chefe do Executivo contra a declaração de inconstitucionalidade dos jabutis na ADI 5.127. Como apontado, seria de se imaginar que o Executivo seria contra a inserção de jabutis, levando em consideração que os dispositivos inseridos inicialmente por ele estariam sendo "trocados" por dispositivos que nem sequer seriam ligados materialmente com o projeto inicial. No entanto, pode-se conjecturar que a

${ }^{28}$ Em resposta à Questão de Ordem 352, de 2013, o então Presidente da Câmara dos Deputados, Henrique Eduardo Alves, decidiu que devolveria à Comissão Mista medidas provisórias que contrariassem os mandamentos legais contidos na Lei Complementar no 95. 
possibilidade de inserção de jabutis aumentaria a capacidade de barganha do Chefe do Executivo com os parlamentares.

A possibilidade de inserção de jabutis seria vantajosa, portanto, de forma dual, para ambos os poderes. Por um lado, beneficiaria o Executivo e, de outro, os parlamentares. Conferiria maior capacidade de barganha do Chefe do Executivo, levando em consideração que uma medida provisória com menor probabilidade de aprovação poderia passar a incluir matérias de interesse dos parlamentares. Os parlamentares, por sua vez, teriam, assim, mais incentivos para converter a medida provisória em lei. Em troca poderiam usar as MPs, cumpre ressaltar que as matérias inseridas através de jabutis talvez nem conseguissem ser aprovadas matérias sem passar pelo através do rito legislativo ordinário, ou demorariam mais caso seguissem esse caminho. Como apontam Limongi e Figueiredo, MPs são um poderoso instrumento nas mãos do Poder Executivo, uma vez que sua têm maior facilidade de aprovação quando comparada aos projetos de lei que passam pelo rito legislativo ordinário. Assim, inserir jabutis em medidas provisórias facilitaria enormemente a aprovação das medidas provisórias e dos próprios dispositivos não conectados tematicamente.

A ADI 5.127, que proibiu a "inserção [...] de matérias de conteúdo temático estranho ao objeto originário da medida provisória" foi ajuizada pela Confederação Nacional das Profissões Liberais (CNPL). O requerente da ADI alegou que o artigo 76 da Lei n. 12.249 de 2010, incluído por emenda parlamentar ao projeto de conversão da medida provisória 472/2009 não tinha relação temática com o objeto original da medida provisória. A CNPL requeria a inconstitucionalidade do artigo, que foi visto como uma ameaça à profissão dos contadores. A ADI não foi julgada procedente, mas o STF vedou - ex nunc - a inserção de jabutis. A questão específica da $\mathrm{ADI}$, no entanto, não é tão importante para a discussão presente.

Antes da ADI, o STF já havia recebido alguns questionamentos acerca da possibilidade de inserção de emendas impertinentes em medidas provisórias, mas os ministros que receberam os processos decidiram que se tratava de matérias interna corporis. Em outras palavras, os Ministros afirmavam que não poderiam interferir por ser uma questão regimental do Congresso, não constitucional. Um dos casos anteriores à ADI 5.127 foi o do Mandado de Segurança 33.615 (BRASIL, 2006). O Ministro Fux negou seguimento ao Mandado com base no argumento de que o controle judicial tem uma sistemática de controle de constitucionalidade repressivo, não prévio e que uma interferência seria violadora do princípio da separação dos poderes (artigo 2ㅜㅡ. CF/88).

Algo muito semelhante ocorreu no Mandado de Segurança 31.444 (BRASIL, 2012), cuja liminar foi negada pela Ministra Rosa Weber. Em 2012, ao analisar uma liminar do Mandado de Segurança, a Ministra Rosa Weber destacou que "a impetração do mandado de segurança visando ao controle preventivo dos atos normativos está adstrita à existência de norma constitucional indicativa de expressa 
proibição ao processamento do aludido projeto de lei". Este caso caracterizaria um assunto interna corporis do Legislativo, não passível de controle prévio.

Assim, pelo menos inicialmente, parece ter havido uma certa deferência em relação à violação das regras pelo Poder Legislativo. Uma interferência do Supremo no processo legislativo poderia levar a um desgaste do Tribunal frente ao Congresso, algo que pode explicar a decisão de não interferir. No entanto, como pode ser visto na ADI 5.127, o Tribunal decidiu intervir, em 2015, no sentido de vedar a inserção de jabutis, de modo que a matéria que - antes considerada meramente regimental - fosse considerada constitucional e sujeita ao controle jurisdicional da Corte. Observa-se, portanto, que a Corte flexibilizou seu próprio entendimento, aumentando seus poderes.

A própria Ministra Rosa Weber, que - três anos antes - havia negado liminar sob argumento de se tratar de matéria interna corporis, muda seu posicionamento na ADI 5.127. Ela afirma que a jurisprudência da Corte acerca da incorporação de emendas parlamentares sem afinidade temática a projetos de lei apresentados pelo Executivo seria pacífica no sentido de proibir tal prática. Assim, a "mesma ratio conduz a que tampouco se admita emenda absolutamente invocatória em rito legislativo sujeito a garantias mais brandas do que as que norteiam o processo legislativo ordinário." Se não havia norma constitucional com proibição expressa da prática em 2012, também não o havia em 2015, de modo que o assunto continuava a ser matéria interna corporis sob a lógica apresentada pela Ministra no MS 31.444.

Cesar van der Laan mapeou as medidas provisórias de janeiro de 2014 e até outubro de 2016, um ano após a decisão do STF. Um dado marcante apresentado foi, que -, dentre as 112 medidas provisórias editadas no período compreendido pelo estudo, -93 foram objeto de apresentação de jabutis. De modo geral, pode-se afirmar - a partir dos dados apresentados no estudo - que a ADI surtiu efeitos. Houve uma diminuição na apresentação de jabutis após a ADI.

Entretanto, é importante ressaltar que o Legislativo, desde a decisão do STF, tem afirmado a existência de graus de conexão de matéria: uma matéria pode ser conexa, completamente desconexa ou apenas relativamente desconexa. Não tem tratado a questão de forma dual, como se um dispositivo pudesse ser considerado pertinente ou impertinente. Embora o Legislativo não esteja violando a decisão do Supremo ou as regras contra incorporação de jabutis de forma deliberada, continuam a inseridas emendas parlamentares relativamente impertinentes. Os parlamentares acharam um caminho de reinterpretar as regras e a decisão da Corte a partir de uma análise diferenciada do que significa pertinência, conexão ou afinidade temática, configurando-se como um caso de criatividade política realizado através de conversion. 


\section{CONCLUSÃo}

Esse artigo mostra o papel decisivo do STF no desenho institucional relativo ao trâmite das MPs, seja formalizando as interpretações ou práticas dos outros Poderes, seja negando-as, como no caso dos Jabutis. Como foi visto, o trâmite das MPs passou por diversas modificações ao longo do tempo. A primeira modificação foi a possibilidade de reedição, que começou como uma prática do Executivo e foi referendada pelo STF na ADI 295. Essa configuração conferia grande poder de agenda ao Executivo, algo que suscitou uma reação por parte de parlamentares, sendo a justificativa principal alegada para a Emenda Constitucional 32 de 2001, que inseriu novas regras no trâmite das MPs.

Com a Emenda, esperava-se uma diminuição na edição de MPs por parte do Executivo e um papel mais ativo do Legislativo. Caso não fossem aprovadas no prazo de 45 dias, as deliberações legislativas da Casa na qual estava tramitando a MP seriam sobrestadas, estabeleceu a MP. Haveria, assim, um desincentivo para que o Presidente da República editasse MPs em excesso, já que o excesso de MPs levaria a uma obstrução do processo legislativo e, consequentemente, não haveria a deliberação das próprias MPs enviadas.

Entretanto, a Emenda teve uma consequência não antecipada: o trancamento de pauta, além de não ter diminuído o número de edições pelo Executivo, diminuiu o poder de agenda do próprio Legislativo, que passou a ter sua pauta controlada pelo Chefe do Poder Executivo. Vieram, então, diversos questionamentos acerca do significado da expressão "deliberações legislativas", que culminou com o entendimento de 2009 do então Presidente da Câmara, Michel Temer. O entendimento estabeleceu que o trancamento de pauta ocorreria somente com projetos de lei ordinária, de modo que o processo legislativo não ficasse mais obstruído de forma significativa. Membros da oposição impetraram um Mandado de Segurança com pedido de liminar no STF. O Ministro Celso de Mello não concedeu a liminar, formalizando a interpretação de Temer, como sendo a única compatível com a Constituição. Oito anos depois, em 2017, o Plenário denegou o Mandado de Segurança.

Outra previsão da EC 32 foi a necessidade de instalação de Comissões Mistas para a apreciação das MPs antes de sua conversão, o que aumentaria o poder de agenda do Legislativo no trâmite. Os parlamentares negligenciaram a regra, criando uma nova regra na Resolução 1 de 2002 que permitia a não instalação das Comissões. O STF, novamente, foi acionado pela oposição e obrigou a instalação das Comissões.

Por fim, outro caso no qual o STF interferiu na prática legislativa foi o dos Jabutis. Embora houvesse regras claras a respeito da impossibilidade de inserção de dispositivos não relacionados tematicamente à $\mathrm{MP}$, os parlamentares negligenciavam tais regras. Em 2015, o STF vedou a prática. 
Observamos, portanto, um paralelo entre todos os casos apresentados. O STF foi um ator decisivo na estabilização das regras referentes ao trâmite das MPs, sendo deferente e formalizando as interpretações de parlamentares quando havia margem para tal (criatividade) e negando práticas claramente transgressoras das regras já existentes. Ainda, os casos mostram que os atores políticos acionam o STF para resolver questões relacionadas ao trâmite legislativo. Neste sentido, o STF se torna uma espécie de árbitro, um "resolvedor" de disputas conjunturais entre os Poderes Executivo e Legislativo e entre a base de governo e de oposição dentro do Legislativo.

Ao atuar assim, a Corte abre a possibilidade de ampliar seu próprio poder de interferir na dinâmica legislativa, como fica claro no caso do entendimento de Temer. A Corte não só referendou a interpretação de Temer, como estabeleceu que entendimentos deste tipo deveriam passar - necessariamente - pelo seu crivo. No caso dos Jabutis, algo semelhante ocorreu: uma questão que era anteriormente considerada regimental, passou a ser considerada constitucional, por interpretação da Corte, podendo - a partir de então - ser decidida pelos Ministros. De forma sutil, a Corte abre a possibilidade de intervenção na dinâmica do processo decisório brasileiro.

\section{REFERÊNCIAS}

ABRANCHES, Sergio. Presidencialismo de Coalizão: raízes e evolução do modelo político brasileiro. São Paulo: Companhia das Letras, 2018.

\section{ABREU JUNIOR, Diogo Alves de. Medidas Provisórias e o Poder Quase}

Absoluto. Brasília: Câmara dos Deputados, Coordenação de Publicações, 2002.

ARGUELHES, Diego Werneck. Old Courts, New Beginiings: judicial constinuity and Constitutional Tranformation in Argentina e Brasil. Tese de Doutorado apresentada à Faculdade de Direito da Universidade Yale (EUA)Yale, New Haven, 2014.

ARGUELHES, Diego Werneck. A Dupla Face das Decisões do STF. Correio Braziliense, Caderno Opinião, 16 abr. 2009.

BRASIL. Supremo Tribunal Federal. Ação Direta de Inconstitucionalidade 293.

Plenário. Relator: Ministro Celso de Mello. Sessão de 06/05/1993. Diário de Justiça, Brasília, DF, 18 jun. 1993. 
BRASIL. Supremo Tribunal Federal. Ação Direta de Inconstitucionalidade 295. Plenário. Relator: Ministro Marco Aurélio. Sessão de 22/06/1990. Diário de Justiça, Brasília, DF, 22 ago. 1997.

BRASIL. Supremo Tribunal Federal. Ação Direta de Inconstitucionalidade 3146. Plenário. Relator: Ministro Joaquim Barbosa. Sessão de 11/05/2006. Diário de Justiça, Brasília, DF, 11 mai. 2006.

BRASIL. Supremo Tribunal Federal. Ação Direta de Inconstitucionalidade 4029. Plenário. Relator: Ministro Luiz Fux. Sessão de 08/03/2012. Diário de Justiça, Brasília, DF, 26 jun. 2012.

BRASIL. Supremo Tribunal Federal. Medida Cautelar do Mandado de Segurança 31.444. Relator: Ministra Rosa Weber. Diário de Justiça, Brasília, DF, 25 jun. 2012.

BRASIL. Supremo Tribunal Federal. Medida Cautelar do Mandado de Segurança 33.557. Relator: Gilmar Mendes. Diário de Justiça, Brasília, DF, 16 dez. 2015.

BRASIL. Supremo Tribunal Federal. Medida Cautelar do Mandado de Segurança 27.931. Relator: Ministro Celso de Mello. Diário de Justiça, Brasília, DF, 16 dez. 2015.

BRASIL. Supremo Tribunal Federal. STF decide que trancamento de pauta da Câmara por MPs não alcança todos os projetos e propostas. Disponível em: < http://www.stf.jus.br/PORTAL/cms/verNoticiaDetalhe.asp?idConteudo=348278>. Acesso em 23 jun. 2019.

BRASIL. Câmara dos Deputados. Questão de Ordem 688/2002 da Câmara dos Deputados. Disponível em:

$<$ https://www2.camara.leg.br/buscaQordem/?wicket:interface=:5::::>. Acesso em 23 jun. 2019.

BRASIL. Câmara dos Deputados. Questão de Ordem 536/2005 da Câmara dos Deputados. Disponível em:

$<$ https://www2.camara.leg.br/buscaQordem/?wicket:interface=:8::::>. Acesso em 23 jun. 2019.

BRASIL. Câmara dos Deputados. Questão de Ordem 539/2005 da Câmara dos Deputados. Disponível em: 
<https://www2.camara.leg.br/buscaQordem/?wicket:interface=:12::::>. Acesso em 23 jun. 2019.

BRASIL. Câmara dos Deputados. Questão de Ordem 56/2007 da Câmara dos Deputados. Disponível em:

https://www2.camara.leg.br/buscaQordem/?wicket:interface=:5:::: > Acesso em 23 jun. 2019.

BRASIL. Câmara dos Deputados. Questão de Ordem 411/2009 da Câmara dos Deputados. Disponível em: <

https://www2.camara.leg.br/buscaQordem/?wicket:interface=:14::::>> Acesso em 23 jun. 2019.

BRASIL. Câmara dos Deputados. Questão de Ordem 394/2014 da Câmara dos Deputados. Disponível em:

https://www2.camara.leg.br/buscaQordem/?wicket:interface=:17::::>. Acesso em 23 jun. 2019.

BRASIL. Câmara dos Deputados. Questão de Ordem 43/2015 da Câmara dos Deputados. Disponível em:

https://www2.camara.leg.br/buscaQordem/?wicket:interface=:10:::: > . Acesso em 23 jun. 2019.

BRASIL. Câmara dos Deputados. Discursos e Notas Taquigráficas da Câmara dos Deputados (Sessão 170.2.54.O). Disponível em:

https://www.camara.leg.br/internet/sitaqweb/TextoHTML.asp?etapa=5\&nuSessao $=170.2 .54 .0 \% 20 \% 20 \% 20 \% 20 \% 20 \&$ nuQuarto=98\&nuOrador $=2 \&$ nuInsercao $=5 \& \mathrm{dtH}$ orarioQuarto=17:14\&sgFaseSessao=OD $\% 20 \% 20 \% 20 \% 20 \% 20 \% 20 \% 20 \% 20 \& D a t a=19$ /06/2012\&txApelido=MARCO $\% 20$ MAIA $\% 20 \% 28$ PRESIDENTE $\% 29, \% 20$ PT-

RS\&txFaseSessao=Ordem $\% 20$ do $\% 20$ Dia $\% 20 \% 20 \% 20 \% 20 \% 20 \% 20 \% 20 \% 20 \% 20 \% 20$ $\% 20 \% 20 \% 20 \% 20 \% 20 \% 20 \% 20 \% 20 \&$ txTipoSessao=Ordin $\%$ C3\%A1ria $\% 20-$ \%20CD \%20\%20\%20\%20\%20\%20\%20\%20\%20\%20\%20\%20\%20\%20\%20\%20\&dtHor aQuarto=17:14\&txEtapa=. Acesso em 23 jun. 2019.

CALIMAN, Auro A. Leis delegadas e medidas provisórias: notas sobre a atividade legislativa do executivo no Brasil. Revista Jurídica "9 de Julho", São Paulo, n. 2, p. 182-203, 2003. 
FIGUEIREDO, Argelina; LIMONGI, Fernando. Executivo e Legislativo na nova ordem constitucional. Rio de Janeiro: Editora FGV, 1999.

LAAN, Cesar R. V. D. Um Panorama Recente da Apresentação de Emendas sem Pertinência Temática a Medidas Provisórias Pós-ADI 5.127. Brasília: Núcleo de Estudos e Pesquisas/CONLEG/Senado (Texto para Discussão nº 244), 2017.

MACHIAVELI, Fernanda. Medidas Provisórias: Os Efeitos Não Antecipados da EC 32 nas Relaç̃oes entre Executivo e Legislativo. 2009. 150f. Dissertação (mestrado) - Faculdade de Filosofia, Letras e Ciências Humanas, Universidade de São Paulo, São Paulo, 2009.

MAHONEY, James; THELEN, Kathleen. Explaining Institutional Change: Ambiguity, Agency, and Power. Cambridge: Cambridge University Press, 2009.

NEVES, Rafael. Câmara altera rito para MPs que trancam a pauta. Congresso em Foco, 2012. Disponível em:

$<$ https://congressoemfoco.uol.com.br/especial/noticias/camara-tera-novo-ritopara-mps-que-trancam-a-pauta/ $\geq$. Acesso em: 23 jun. 2019.

NORTH, Douglas. Institutions, Institutional Change and Economic Performance. Cambridge: Cambridge University Press, 1990.

OLIVEIRA, João Paulo de. Medidas Provisórias na Emenda Constitucional 32. Revista Virtual da AGU, Brasília, ano III, no 18, 2002.

OLIVEIRA, Magali Carvalho Alves de. Medidas provisórias e a relação Executivo x Legislativo: uma visão do sobrestamento de pauta. 2009. ???f. Monografia (especialização) -- Curso de Instituições e Processos Políticos do Legislativo, Câmara dos Deputados, Centro de Formação, Treinamento e Aperfeiçoamento (Cefor), Brasília.

PIERSON, Paul. Politics in Time - History, Institutions, and Social Analysis. Princeton: Princeton Universtity Press, 2004.

PIRES, Ednilton Andrade. As medidas provisórias e o sobrestamento das demais deliberações legislativas. 2008. Monografia (especialização) -- Centro de Formação, Treinamento e Aperfeiçoamento (Cefor) da Câmara dos Deputados, Curso de Especialização em Processo Legislativo, Brasília. 
SHEINGATE, Adam. Rethinking Rules: Creativity and Constraint in the U.S. House Representatives. In: MAHONEY, James; THELEN, Kathleen. Explaining Institutional Change: Ambiguity, Agency, and Power. Cambridge: Cambridge University Press, 2010.

SHEPSLE, Kenneth A.. Rule Breaking and Political Imagination. Chicago: The University Chicago Press, 2017.

TSEBELIS, George. Veto Players: How Political Institutions Work. New Jersey: Princeton University Press, 2002. 